\title{
GATA1 Gene Mutation
}

National Cancer Institute

\section{Source}

National Cancer Institute. GATA1 Gene Mutation. NCI Thesaurus. Code C82340.

A change in the nucleotide sequence of the GATA1 gene. 